Gut, 1988, 29, 1721-1724

\title{
Benign oesophageal stricture in Barrett's columnar epithelialised oesophagus and its responsiveness to conservative management
}

\author{
M ATKINSON AND C S ROBERTSON \\ From the Department of Surgery, University Hospital, Queen's Medical Centre, Nottingham
}

SUMMARY The response to treatment of peptic oesophageal stricture associated with columnar lined (Barretts) oesophagus (CLO) has been compared with that in peptic stricture without CLO. Benign oesophageal stricture was present in $23(41 \%)$ of 56 patients consecutive with CLO. In 18 the stricture lay at the squamocolumnar mucosal junction and was associated with reflux oesophagitis, in five it was situated in the columnar lined segment and in four of these it was known to have been preceded by a chronic ulcer at the site of the stricture. Controls were an age and sex matched group of patients with benign stricture related to reflux oesophagitis unassociated with columnar epithelialisation. CLO associated strictures involving squamous mucosa were situated significantly $(p<0 \cdot 01)$ higher in the oesophagus than non-CLO strictures. The response to endoscopic dilatation and active medical treatment was significantly better, as judged by the need for subsequent dilatation $(p<0.01)$ in the CLO than in the non-CLO group. It is concluded that associated columnar epithelialisation of the oesophagus is not in itself an indication for antireflux surgery in the management of benign stricture and these usually respond well to dilatation and medical treatment.

In his original description of the columnar epithelial lined oesophagus (CLO) Barrett ${ }^{1}$ mentioned that a fibrous stricture may develop at the junction of squamous and columnar lined segments as a result of reflux oesophagitis. Since then benign oesophageal stricture has been recognised as a common complication of the columnar lined oesophagus in adults ${ }^{2-8}$ and children ${ }^{10}$ (Table 1). Acid gastro-oesophageal reflux is often severe" and oesophageal emptying has been reported to be impaired ${ }^{12}$ in patients with CLO. These factors might be expected to reduce the responsiveness of oesophagitis and benign stricture to treatment.

In this study a comparison has been made between benign oesophageal stricture in patients with gastrooesophageal reflux with and in those without columnar lined oesophagus.

\section{Methods}

PATIENTS

In 23 of 56 consecutive patients found to have columnar epithelial lined oesophagus, endoscopy

Address for correspondence: Professor M Atkinson, Dept of Surgery, University Hospital, Queen's Medical Centre, Nottingham NG7 2UH.

Received for publication 30 June 1988. revealed a benign oesophageal fibrous stricture which required treatment. For the purposes of this study a stricture was defined as one not easily admitting a $12 \mathrm{~mm}$ diameter fibreoptic endoscope. The diagnosis of columnar lined oesophagus was

Table 1 Oesophageal stricture in columnar lined (Barrett's) oesophagus

\begin{tabular}{|c|c|c|c|c|}
\hline \multirow[b]{2}{*}{ Authors } & \multirow[b]{2}{*}{$\begin{array}{l}\text { Patients } \\
\text { (n) }\end{array}$} & \multirow{2}{*}{$\begin{array}{l}\text { With } \\
\text { stricture } \\
(\%)\end{array}$} & \multicolumn{2}{|c|}{$\begin{array}{l}\text { Site of stricture } \\
\text { Relative to } S C \\
\text { junction }\end{array}$} \\
\hline & & & $\begin{array}{l}\text { At } \\
\text { or above }\end{array}$ & Below \\
\hline \multicolumn{5}{|l|}{ Adults } \\
\hline Burgess et al (1971) & 17 & $65 \%$ & $65 \%$ & $0 \%$ \\
\hline Robbins et al (1977) & 26 & $81 \%$ & & \\
\hline Savery \& Miller (1978) & 108 & $38 \%$ & & \\
\hline Sarr et al (1985) & 44 & $31 \%$ & & \\
\hline Kerlin et al (1986) & 50 & $38 \%$ & $18 \%$ & $20 \%$ \\
\hline Winters et al (1987) & 12 & $33 \%$ & & \\
\hline Cooper \& Barbezat (1987) & 52 & $19 \%$ & & \\
\hline Present series & 56 & $41 \%$ & $32 \%$ & $9 \%$ \\
\hline \multicolumn{5}{|l|}{ Children } \\
\hline Dahms \& Rothstein (1984) & 13 & $38 \%$ & & \\
\hline Hassall et al (1985) & 11 & $73 \%$ & $73 \%$ & \\
\hline
\end{tabular}


Table 2 Comparison of oesophageal strictures in Barrett and non-Barrett patients.

\begin{tabular}{|c|c|c|}
\hline & $\begin{array}{l}\text { Columnar lined } \\
\text { (Barrett's) } \\
\text { oesophagus }\end{array}$ & $\begin{array}{l}\text { Stricture without } \\
\text { oesophageal } \\
\text { columnar } \\
\text { epithelialisation }\end{array}$ \\
\hline $\begin{array}{l}\text { Patients }(\mathrm{n}) \text { men } \\
\text { Mean age in yrs (range) } \\
\text { Mean duration of } \\
\text { dysphagia before } \\
\text { initial } \\
\text { dilatation in months } \\
\text { (range) }\end{array}$ & $\begin{array}{l}23(11) \\
69(33-84) \\
42 \cdot 5(1-240)\end{array}$ & $\begin{array}{l}23(11) \\
70)(27-90) \\
30 \cdot 8(2-216)\end{array}$ \\
\hline $\begin{array}{l}\text { Epithelium at stricture site } \\
\text { Patients ( } \mathrm{n} \text { ) } \\
\text { Mean period of follow } \\
\text { up in years (range) }\end{array}$ & $\begin{array}{cc}\text { Squamous } & \text { Columnar } \\
18 & 5 \\
5 \cdot 14 & 6 \cdot 0 \\
(1-10) & (1 \cdot 5-9) \\
& \text { NS }\end{array}$ & $\begin{array}{l}\text { Squamous } \\
23 \\
3 \cdot 63 \\
(1-10) \\
1\end{array}$ \\
\hline $\begin{array}{l}\text { Mean distance of stricture } \\
\text { from alveolar margin in } \\
\mathrm{cm} \text { (range) }\end{array}$ & $\begin{array}{cc}27 \cdot 9 & 34 \cdot 2 \\
(22-36) & (30-36) \\
L & p<0 \cdot 05\end{array}$ & $\begin{array}{c}33 \cdot 1 \\
(27-40) \\
1\end{array}$ \\
\hline $\begin{array}{l}\text { Mean distance of stricture } \\
\text { above cardia in } \mathrm{cm} \\
\text { (range) }\end{array}$ & $\begin{array}{cc}7 \cdot 83 & <1 \cdot 0 \\
(5-12) & (0-2) \\
\text { L } & <0 \cdot(01\end{array}$ & $\begin{array}{c}1 \cdot 1 \\
(0-2) \\
1\end{array}$ \\
\hline $\begin{array}{l}\text { Mean diameter of stricture } \\
\text { before dilatation in } \mathrm{mm} \\
\text { (range) }\end{array}$ & $\begin{array}{cc}8 \cdot 7 & 8 \cdot 4 \\
(4-12) & (5-10) \\
L & N S \\
\end{array}$ & $\begin{array}{c}8 \cdot() 9 \\
(2-12) \\
1\end{array}$ \\
\hline $\begin{array}{l}\text { Mean number of } \\
\text { dilatations per pt/year } \\
\text { follow up (range) }\end{array}$ & $\begin{array}{ll}(0.55 & (0.23 \\
(0.22-1.43) & (0 \cdot 11-0) \cdot 66)\end{array}$ & $\begin{array}{l}1 \cdot 39 \\
(0 \cdot 25-4 \cdot 5)\end{array}$ \\
\hline
\end{tabular}

made at endoscopy if there was circumferential replacement of squamous by columnar epithelium for at least $5 \mathrm{~cm}$ above the cardia. For comparative purposes 23 patients, also attending the unit during the same 10 year period, with benign oesophageal stricture without columnar epithelialisation were studied. These were matched for age and sex with the columnar lined oesophagus group but their mean follow up period after the initial dilatation was somewhat shorter as was the mean duration of dysphagia before the initial dilatation (Table 2). A history of previous ingestion of non-steroidal antiinflammatory drugs was obtained in two of the CLO group and in four of the non-CLO group.

At endoscopy the presence and extent of oesophagitis were assessed and the distances from the alveolar margin to the stricture, to the cardia and to the diaphragmatic hiatus were measured. The diameter of the stricture was estimated using the opened biopsy forceps as a measure and dilatation using metal olive dilators was done to a diameter of $18 \mathrm{~mm}$ (54 FG olive). After the initial dilatation longterm therapy with cimetidine $1.2 \mathrm{~g}$ daily or ranitidine $300 \mathrm{mg}$ daily and asilone gel $10 \mathrm{ml}$ qds was commenced and the patient was followed up at intervals of three to six months with endoscopy repeated at yearly intervals or more frequently if demanded by symptoms.

\section{Results}

The incidence of benign stricture was $41 \%$ in the 56 patients with CLO. The stricture was situated at the squamocolumnar junction in 18 and in the columnar lined oesophagus in the remaining five. In four of these five patients the stricture lay at the site of a previous chronic ulcer seen at an earlier endoscopy and these had all healed with medical treatment. The predilatation luminal diameter of every stricture in the CLO and non-CLO group was $12 \mathrm{~mm}$ or less.

The strictures were situated significantly nearer the alveolar margin in the CLO group than in the nonCLO group (Table 2). A hiatal hernia was found to be present in 22 of the CLO group and in 21 of the non-CLO group. This cephalad shift of the cardia, however, did not account for the higher position of the strictures in the oesophagus in the CLO group because the distance of the stricture above the cardia was significantly greater in this group. Oesophagitis with ulceration was found in and above the stricture in $13(56 \%)$ of the 23 patients with non-CLO strictures and in $14(79 \%)$ of the 18 patients with CLO strictures involving squamous mucosa. Its severity was thus comparable between the two groups. Only one of five patients in which the stricture involved the columnar epithelialised oesophagus, had evidence of oesophagitis in the squamous mucosa.

The numbers of dilatations required are shown in the Figure where it will be seen that strictures associated with CLO required rather fewer dilatations. As the mean follow up period was shorter (although not significantly so) in the non-CLO group these figures were expressed as the mean number of dilatations needed per patient year (Table 2). The CLO group required significantly fewer dilatations than did the non-CLO group. There was no significant difference in the responsiveness to treatment between those strictures at or above the squamocolumnar junction and those in the columnar lined portion of the oesophagus and four of the five in the latter group have needed only a single dilatation.

\section{Discussion}

This study provides further evidence that benign stricture of the oesophagus is a common complication of the columnar lined oesophagus. Whilst three studies have reported strictures in $65-81 \%$ of patients 


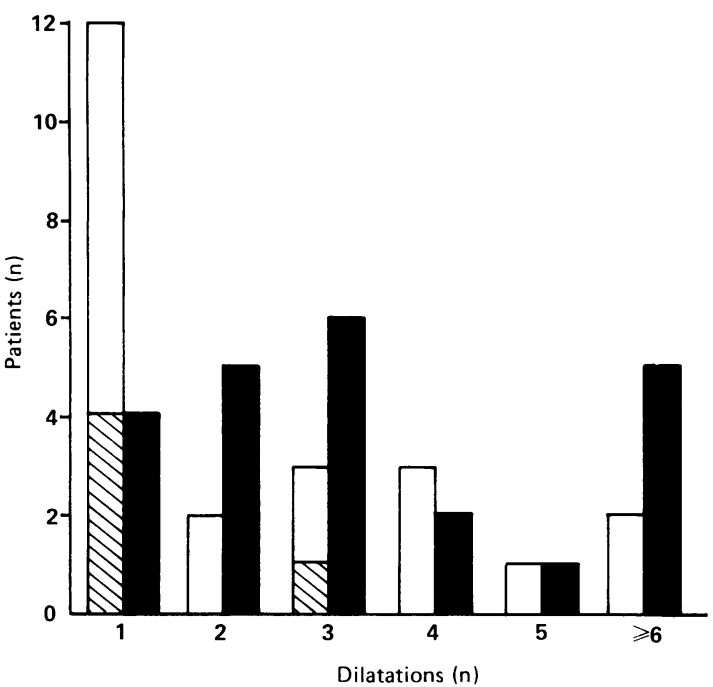

Figure Number of dilatations required in patients with oesophageal strictures in columnar lined oesophagus (left hand columns) and in non columnar lined oesophagus (right hand columns). The hatched areas represent strictures in the columnar lined oesophagus and the open areas strictures at the squamocolumnar junction.

with CLO our findings are in keeping with the frequency of $30-40 \%$ reported in most of the larger series (Table 1). The presence of CLO should always be suspected when a stricture is found in the midoesophagus which is the characteristic situation. In several series, however, lower oesophageal strictures have also been reported. ${ }^{35}$ The extent of the columnar epithelialisation varies greatly and it is difficult to be certain where distal strictures lie in relation to the squamocolumnar junction unless endoscopy and mucosal biopsy are done. The present study clearly shows that a minority of strictures in CLO lay well below the squamo columnar junction. In four of the five strictures involving the columnar lined portion of the oesophagus the site corresponded with that of a chronic ulcer seen at a previous endoscopy which had subsequently healed. This emphasises that benign stricture in CLO may be of two types; the first occurs at the squamo columnar mucosal junction and results from reflux oesophagitis whilst the second lies in the columnar lined segment and follows healing of a chronic ulcer with scarring.

Oesophageal $\mathrm{pH}$ monitoring in the lower oesophagus reveals more severe gastro-oesophageal acid reflux in patients with CLO than in those with severe non-CLO associated reflux oesophagitis necessitating antireflux surgery." Both $\mathrm{pH}$ monitoring" and scintiscanning ${ }^{12}$ reveal impaired oesophageal acid clearance in CLO even when there is no associated stricture but of course these may also be found in non-CLO associated oesophagitis. Oesophageal acid perfusion studies suggest that sensitivity to $\mathrm{HCL}$ of the oesophageal mucosa in CLO is significantly reduced when compared with non-CLO associated reflux oesophagitis. ${ }^{13}$ All these factors might tend to increase the severity of reflux oesophagitis and hence benign stricture in CLO might be expected to be relatively refractory to treatment. Our findings rather surprisingly indicated that strictures associated with CLO were more responsive to treatment and required less frequent dilatation than did nonCLO associated reflux strictures. The reason for this difference is not obvious but it might be that medical treatment is more effective in reducing the acidity in the mid than in the lower oesophagus. Useful information would be yielded by oesophageal $\mathrm{pH}$ monitoring with an electrode positioned above the squamocolumnar mucosal junction in patients with CLO.

Whatever the merits of antireflux surgery in preventing or alleviating other complications of Barrett's oesophagus, the presence of CLO is not in itself an indication for their use in the management of benign oesophageal stricture. High strictures in CLO may present technical difficulties at operation and our findings suggest that the majority of patients can be effectively treated by endoscopic dilatation and active medical measures to control reflux.

\section{References}

1 Barrett NR. Chronic peptic ulcer of the oesophagus and oesophagitis. Br J Surg 1950; 38: 175-82.

2 Burgess JN, Payne WS, Anderson HA. Weiland LH, Carlson HC. Barrett esophagus: the columnar epithelial lined esophagus. Mayo Clinic Proc 1971; 46: 728-34.

3 Robbins AH, Hermos JA, Schimmel EM, Friedlander DM, Messian RA. The columnar lined oesophagus. Radiology 1977; 123: 1-7.

4 Savary M. Miller G. The esophagus - handbook and atlas of endoscopy. Solothurn, Switzerland: Verlag Gassmann AG, 1978.

5 Sarr MG, Hamilton SR, Marrone GC, Cameron JL. Barrett's esophagus: its prevalence and association with adenocarcinoma in patients with symptoms of gastro esophageal reflux. Am J Surg 1985; 149: 187-93.

6 Kerlin P, D’Mellon G, Van Deth A. Barrett's oesophagus clinical endoscopic and histologic spectrum in fifty patients. Aust NZ J Med 1986; 16: 198-205.

7 Winters C, Spurling TJ, Chobanian SJ, et al. Barrett's esophagus - a prevalent occult complication of gastro esophageal reflux discase. Gastroenterology 1987; 92: 118-24.

8 Cooper BT, Barbezat GO. Barrett's oesophagus: a clinical study of 52 patients. $Q J$ Med 1987; 62: 97-108.

9 Dahms BB, Rothstein FC. Barrett's esophagus in children: a consequence of chronic gastro esophacal reflux. Gastroenterology 1984; 86: 318-23. 
10 Hassall E, Weinstein WM, Amen ME. Barrett's esophagus in childhood. Gastroenterology 1985; 89: 1331-7.

11 Gillen P, Keeling P, Byrne PJ, Hennessy TPJ. Barrett's oesophagus: pH profile. Br J Surg 1987; 74: 774-6.

12 Karvelis KC, Draine WE, Johnson DA, Silverman ED.
Barrett's esophagus. Decreased esophageal clearance shown by radionuclide esophageal scintigraphy. Radiology 1987; 162: 97-9.

13 Johnson DA, Winters C, Spurling TJ, Chobanian SJ, Cattau EL. Esophageal acid sensitivity in Barrett's csophagus. J Clin Gastroenterol 1987; 9: 23-7. 